\title{
The Mannich Reaction of Malonates with Simple Imines Catalyzed by Bifunctional Cinchona Alkaloids: Enantioselective Synthesis of $\beta$-Amino Acids
}

\author{
Jun Song, Yi Wang, and Li Deng* \\ Department of Chemistry, Brandeis University, Waltham, Massachusetts 02454-9110
}

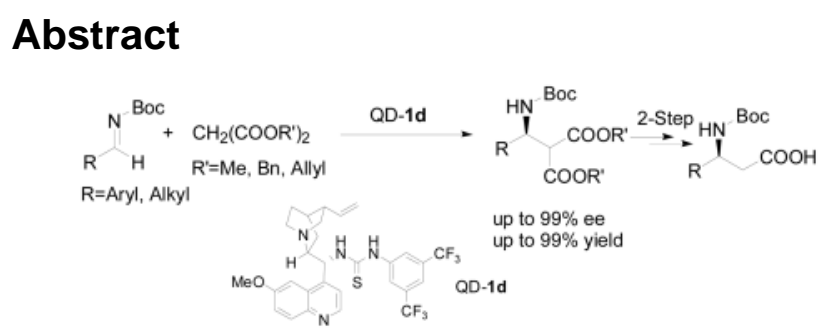

We describe the first efficient, direct asymmetric Mannich reactions with malonates and $N$-Boc aryl and alkyl imines by cooperative hydrogen bonding catalysis with a cinchona alkaloid bearing a thiourea functionality. We have also extended the scope of this reaction to $\beta$-ketoesters. The synthetic value of this new reaction is demonstrated in the establishment of a convergent enantioselective route toward the biologically important $\beta$-amino acids under mild and air- and moisture-tolerant conditions.

Enantioselective Mannich reactions ${ }^{1}$ are of fundamental importance to the synthesis of optically active chiral amines. Significant progress has been made in the development of efficient chiral metal and organic catalysts for enantioselective Mannich reactions with preactivated enolate nucleophiles such as enolsilane ${ }^{2}$ and enolizable carbonyl nucleophiles such as $\beta$-keotesters ${ }^{3 \mathrm{a}-\mathrm{c}}$ and 1,3-diketones. ${ }^{3 \mathrm{~d}}$ Highly enantioselective, direct Mannich reactions with aldehydes and ketones have also been accomplished with chiral secondary amines and chiral metal complexes. ${ }^{4}$ However, a highly enantioselective Mannich reaction of malonates with simple imines ${ }^{5}$ remains elusive, although, if successfully promoted with a practically accessible chiral catalyst under air- and moisture-tolerant conditions, it could provide a highly attractive, convergent approach toward optically active $\beta$-amino acids suitably protected for further synthetic elaborations. ${ }^{6,7}$ The realization of such a direct Mannich reaction is particularly challenging as it involves the combination of an weakly reactive imine and a carbonyl nucleophile that is, relatively to 1,3-diketones and $\beta$ ketoesters, harder to enolize and unsuitable for chiral enamine catalysis. ${ }^{5}$ Herein, we wish to describe the application of cooperative hydrogen bonding catalysis to develop a cinchona alkaloid-catalyzed, highly enantioselective Mannich reaction with malonates and $N$-Boc imines.

Chiral hydrogen-bond donors such as chiral thioureas and phosphoric acid have been identified as effective catalysts for the activation of simple imines toward various enantioselective nucleophilic additions ${ }^{8}$ including Mannich reactions with enolsilane ${ }^{2 e, f}$ and 1,3-diketones. ${ }^{3 \mathrm{~d}}$ On the other hand, chiral hydrogen-bond acceptors such as cinchona 
alkaloids were shown to be effective for the activation of malonates for enantioselective conjugate additions. ${ }^{9}$ These observations led us to envision that cinchona alkaloid derivatives bearing a thiourea functionality $8 \mathrm{j}, 10$ might act as efficient bifunctional catalysts for a Mannich reaction of malonates with simple imines.

Accordingly, we initiated a study of cinchona alkaloid derivatives bearing either a 6'- or 9thiourea functionality (Figure 1) as catalysts for the addition of dimethyl malonate 5a to the $N$-Boc-protected imine 4D in dichloromethane. As summarized in Table 1, 6'- or 9-thiourea cinchona alkaloids bearing an electron-withdrawing aryl substituent emerged as the most effective catalysts. The Mannich reaction with catalysts Q-1d and $\mathbf{3}$ took place in 77\% and $72 \%$ ee, respectively (entries 4 and 7 ). A study of the reaction with the synthetically more accessible Q-1d in various solvents identified acetonitrile and acetone as suitable alternatives to dichloromethane (entries 8 and 9). Interestingly, reactions in these solvents responded differently to temperature change. For reactions at $-20^{\circ} \mathrm{C}$ vs. those at room temperature, the enantioselectivity was slightly increased in dichloromethane but decreased noticeably in acetonitrile. A more pronounced positive temperature effect on the enantioselectivity was observed in acetone, which led us to a highly enantioselective, completed reaction of $\mathbf{4 D}$ with $\mathbf{5 a}$ at $-60{ }^{\circ} \mathrm{C}$ (entry 13).

The scope of the enantioselective Mannich reaction catalyzed by both Q-1d and QD-1d was investigated under the optimized condition identified above (Table 2). The enantioselectivity of catalyst $\mathbf{1 d}$ was found to be nearly independent of the steric properties of the aryl imines. Reactions with $o-, m$ - and $p$-tolyl imines (4B-D) in the presence of QD-1d took place in 97$99 \%$ ee. Exceedingly high enantioselectivity could also be obtained for a variety of heteroaryl and aryl imines of varying electronic properties $(\mathbf{4 E}-\mathbf{I})$, including electron-rich aryl imines. ${ }^{2 \mathrm{f}}$ It is noteworthy that very good enantioselectivity could be attained for $\mathrm{N}$-Boc alkyl imines, including even $\alpha$-unbranched alkyl imines $(\mathbf{4 M}-\mathbf{O}) .{ }^{\text {aa }}$ Although high loading of QD-1d (100 mol\%) was required to sustain a useful level of enantioselectivity, QD-1d could be readily recycled in greater than $95 \%$ yield. To our knowledge, the results with $\mathbf{4 M -}$ $\mathbf{N}$ represent the first highly enantioselective Mannich reactions with $N$-Boc $\alpha$-unbranched alkyl imines (entries 13-14). Catalyst 1d also tolerated malonates of different bulk. This allows the conversion of amine $\mathbf{6}$ to $\beta$-amino acid $\mathbf{7}$ without using strongly acidic or basic conditions (Scheme 1).

The 1d-catalyzed Mannich reaction is also applicable to $\beta$-ketoesters (Table 3). ${ }^{3 a-c}$ Importantly, steric variations of the keto substituent are readily accepted by catalyst 1d, thereby allowing the Mannich reaction to provide access to a wide variety of optically active $\beta$-amino ketones.

In conclusion, by exploring cooperative hydrogen-bonding catalysis with a readily accessible bifunctional cinchona alkaloid catalyst, $,, 10,11$ we have developed a highly enantioselective direct Mannich reactions of $N$-Boc aryl and alkyl imines with malonates and $\beta$-ketoesters. ${ }^{12}$ This leads to the establishment of a convergent enantioselective synthesis of $N$-Boc $\beta$-amino acids from readily available starting materials under mild, moisture- and air-compatible conditions.

\section{Supplementary Material}

Refer to Web version on PubMed Central for supplementary material.

\section{Acknowledgments}

We are grateful for the generous financial support from National Institutes of Health (GM-61591). We are grateful to Dr. Jeffrey Agar, and Ms. Qi Wang and Mr. Murat Karabacak for HRMS analysis 


\section{References}

1. For reviews, see: (a) Córdova A. Acc Chem Res. 2004; 37:102. [PubMed: 14967057] (b)Kobayashi S, Ueno M. Jacobsen EN, Pfaltz A, Yamamoto H. Comprehensive Asymmetric Catalysis Supplement I. SpringerBerlin2003; Chapter 29.5(c) Kobayashi S, Ishitani H. Chem Rev. 1999; 99:1069. [PubMed: 11749440] and reference therein.

2. (a) Kobayashi S, Ueno M, Saito S, Mizuki Y, Ishitani H, Yamashita Y. Proc Natl Acad Sci USA. 2004; 101:5476. [PubMed: 15067139] (b) Akiyama T, Itoh J, Yokota K, Fuchibe K. Angew Chem Int Ed. 2004; 43:1566.(c) Josephsohn NS, Snapper ML, Hoveyda AH. J Am Chem Soc. 2004; 126:3734. [PubMed: 15038725] (d) Kobayashi S, Matsubara R, Nakamura Y, Kitagawa H, Sugiura M. J Am Chem Soc. 2003; 125:2507. [PubMed: 12603138] (e) Wenzel AG, Lalonde MP, Jacobsen EN. Synlett. 2003:1919.(f) Wenzel AG, Jacobsen EN. J Am Chem Soc. 2002; 124:12964. [PubMed: 12405820] (g) Kobayashi S, Hamada T, Manabe K. J Am Chem Soc. 2002; 124:5640. [PubMed: 12010028]

3. (a) Lou S, Taoka BM, Ting A, Schaus SE. J Am Chem Soc. 2005; 127:11256. [PubMed: 16089450] (b) Hamashima Y, Sasamoto N, Hotta D, Somei H, Umebayashi N, Sodeoka M. Angew Chem Int Ed. 2005; 44:1525.(c) Poulsen TB, Alemparte C, Saaby S, Bella M, Jørgensen KA. Angew Chem Int Ed. 2005; 44:2.(d) Uraguchi D, Terada M. J Am Chem Soc. 2004; 126:5356. [PubMed: 15113196]

4. (a) Trost BM, Jaratjaroonphong J, Reutrakul V. J Am Chem Soc. 2006; 128:2778. [PubMed: 16506738] (b) Mitsumori S, Zhang H, Cheong P, Houk KN, Tanaka F, Barbas CF III. J Am Chem Soc. 2006; 128:1040. [PubMed: 16433496] (c) Kano T, Yamaguchi Y, Tokuda O, Maruoka K. J Am Chem Soc. 2005; 127:16408. [PubMed: 16305223] (d) Harada S, Handa S, Matsunaga S, Shibasaki M. Angew Chem Int Ed. 2005; 44:4365.(e) Okada A, Shibuguchi T, Ohshima T, Masu H, Yamaguchi K, Shibasaki M. Angew Chem Int Ed. 2005; 44:4564.(f) Notz W, Watanabe SI, Chowdari NS, Zhong G, Betancort JM, Tanaka F, Barbas CF III. Adv Synth Catal. 2004; 346:1131. (g) Zhuang W, Saaby S, Jørgensen KA. Angew Chem Int Ed. 2004; 43:4476.(h) Córdova A. Chem Eur J. 2004; 10:1987.(i) Notz W, Tanaka F, Barbas CF III. Acc Chem Res. 2004; 37:5801.(j) Hayashi Y, Tsuboi W, Ashimine I, Urushima T, Shoji M, Sakai K. Angew Chem Int Ed. 2003; 42:3805.(k) List B, Pojarliev P, Biller WT, Martin HJ. J Am Chem Soc. 2002; 124:827. [PubMed: 11817958] (1) List B. J Am Chem Soc. 2000; 122:9336.

5. Only one Mannich reaction with malonates and an activated N-tosyl- $\alpha$-imino ester in $39-87 \%$ ee has been reported: Marigo M, Kjærsgaard A, Juhl K, Gathergood N, Jørgensen KA. Chem Eur J. 2003; 9:2359.

6. For reviews on the synthesis of $\beta$-amino acids: (a) Ma J. Angew Chem Int Ed. 2003; 42:4290.(b) Magriotis PA. Angew Chem Int Ed. 2001; 40:4377.(c) Liu M, Sibi MP. Tetrahedron. 2002; 58:7991.

7. For recent synthesis of $\beta$-amino acids: (a) Berkessel A, Cleemann F, Mukherjee S. Angew Chem Int Ed Engl. 2005; 44:2.(b) Hsiao Y, Rivera NR, Rosner T, Krska SW, Njolito E, Wang F, Sun Y, Armstrong JD, Grabowski EJ, Tillyer RD, Spindler F, Malan C. J Am Chem Soc. 2004; 126:9918. [PubMed: 15303855] (c) Zhou Y, Tang W, Wang W, Li W, Zhang X. J Am Chem Soc. 2002; 124:4952. [PubMed: 11982347] (d) Sibi MP, Asano Y. J Am Chem Soc. 2001; 123:9708. [PubMed: 11572706] (e) Myers J, Jacobsen EN. J Am Chem Soc. 1999; 121:8959.

8. (a) Yoon TP, Jacobsen EN. Angew Chem Int Ed. 2005; 44:466.(b) Yoon TP, Jacobsen EN. Science. 2003; 299:1691. [PubMed: 12637734] (c) Vachal P, Jacobsen EN. J Am Chem Soc. 2002; 124:10012. [PubMed: 12188665] (d) Vachal P, Jacobsen EN. Org Lett. 2000; 2:867. [PubMed: 10754690] (e) Sigman MS, Vachal P, Jacobsen EN. Angew Chem Int Ed. 2000; 39:1279.(f) Sigman MS, Jacobsen EN. J Am Chem Soc. 1998; 120:4901.(g) Xu X, Furukawa T, Okino T, Miyabe H, Takemoto Y. Chem Eur J. 2006; 12:466.(h) Okino T, Nakamura S, Furukawa T, Takemoto Y. Org Lett. 2004; 6:625. [PubMed: 14961639] (i) Okino T, Hoashi Y, Takemoto Y. J Am Chem Soc. 2003; 125:12672. [PubMed: 14558791] (j) Bernardi L, Fini F, Herrera RP, Ricci A, Sgarzani V. Tetrehedron. 2006; 62:375.

9. Li H, Wang Y, Tang L, Deng L. J Am Chem Soc. 2004; 126:9906. [PubMed: 15303849]

10. Catalyst 1d, accessible in two steps from quinine or quinidine, was reported by (a) Li B, Jiang L, Liu M, Chen Y, Ding L, Wu Y. Synlett. 2005; 4:603.and (b) Vakulya B, Varga S, Csámpai A, Soós T. Org Lett. 2005; 7:1967. [PubMed: 15876031] For recent applications see: (c) Mccooey 
SH, Connon SJ. Angew Chem Int Ed. 2005; 44:6367.(d) Ye J, Dixon DJ, Hynes P. Chem Commun. 2005; 35:4481.

11. (a) Li H, Wang B, Deng L. J Am Chem Soc. 2006; 128:732. [PubMed: 16417358] (b) Wu F, Li H, Hong R, Deng L. Angew Chem Int Ed. 2006; 44:947.(c) Li H, Song J, Liu X, Deng L. J Am Chem Soc. 2005; 127:8948. [PubMed: 15969561] (d) Li H, Wang Y, Tang L, Wu F, Liu X, Guo C, Foxman BM, Deng L. Angew Chem Int Ed. 2005; 44:105.(e) Liu X, Li H, Deng L. Org Lett. 2005; 7:167. [PubMed: 15646949]

12. After the submission of this paper, a study outlining a Mannich reaction of malonates and $\beta$ ketoesters to N-Boc aryl imines was reported online: Tillman AL, Ye J, Dixon DJ. Chem Commun. 2006:1191. 


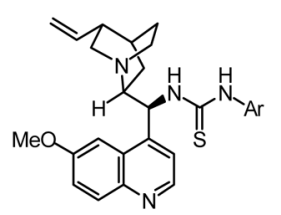

Q-1

1a $\mathrm{Ar}=4-t-\mathrm{Bu}-\mathrm{Ph}-; \mathbf{1 b} \mathrm{Ar}=2-i-\mathrm{Pr}-\mathrm{Ph}-;$

1c $\mathrm{Ar}=\mathrm{Ph}-; \mathbf{1 d ~ A r}=3,5-$ bis $_{3} \mathrm{CF}_{3} \mathrm{Ph}$ -

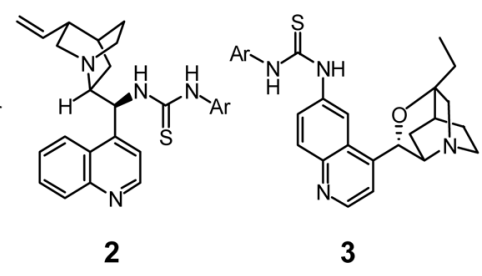

2,3: $\mathrm{Ar}=3,5-\mathrm{bisCF}_{3} \mathrm{Ph}$

Figure 1.

C6' or C9 thiourea cinchona alkaloid derivatives. 


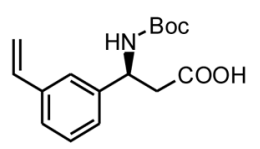

7Lc, $96 \%$ ee, $72 \%$ yield from $6 \mathrm{Lc}$

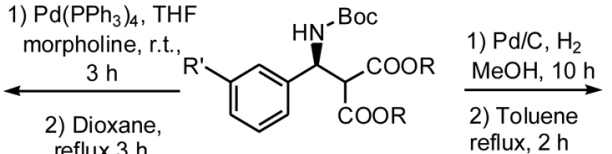

6Ab, R =Bn, R' =H, 96\%ee 6Lc, $R=$ Allyl, R' = Vinyl, $96 \%$ ee

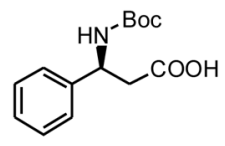

7Ab, 94\% ee, $76 \%$ yield from $\mathbf{6 A b}$

Scheme 1.

Synthesis of $N$-Boc- $\beta$-amino acids 


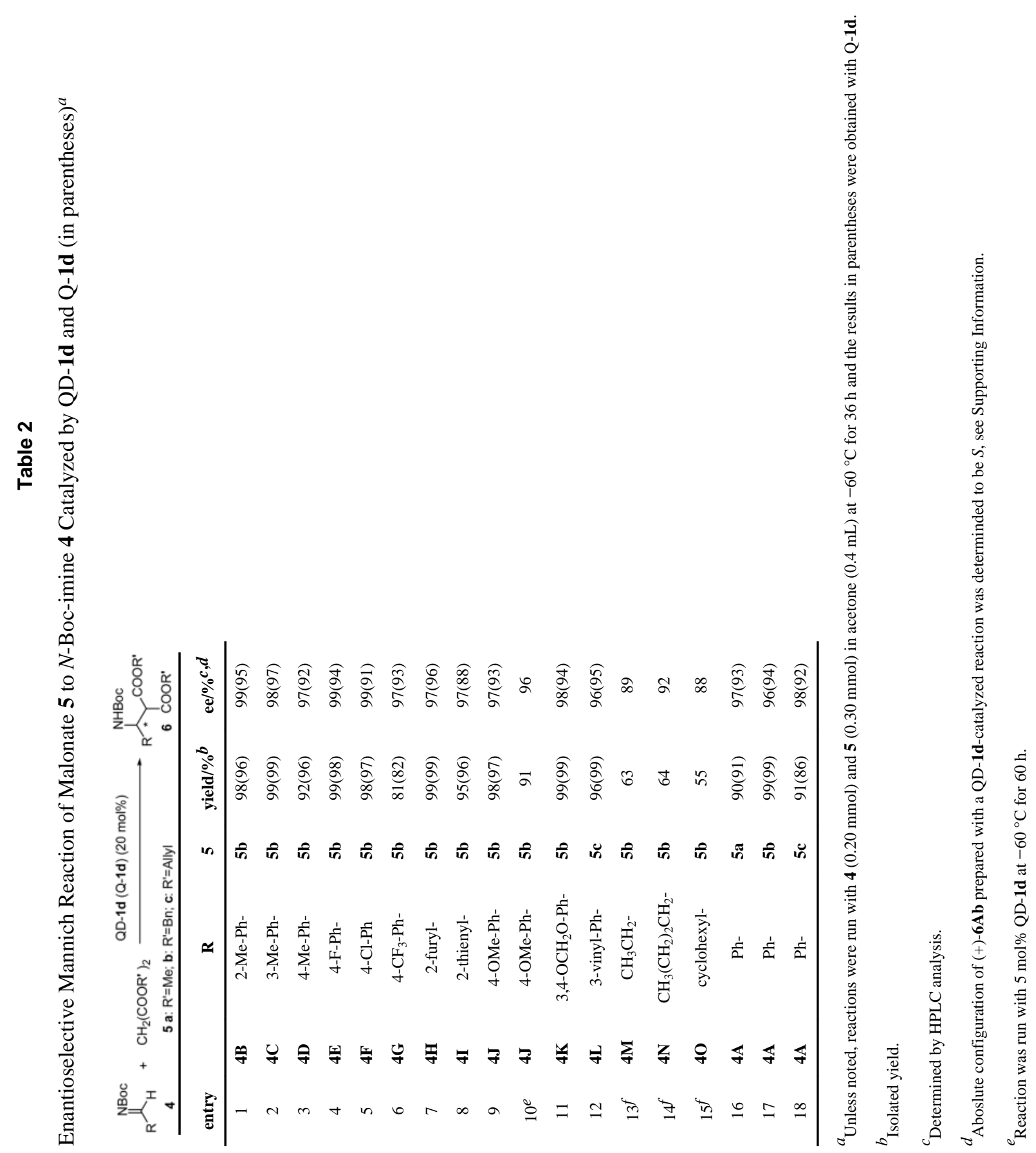




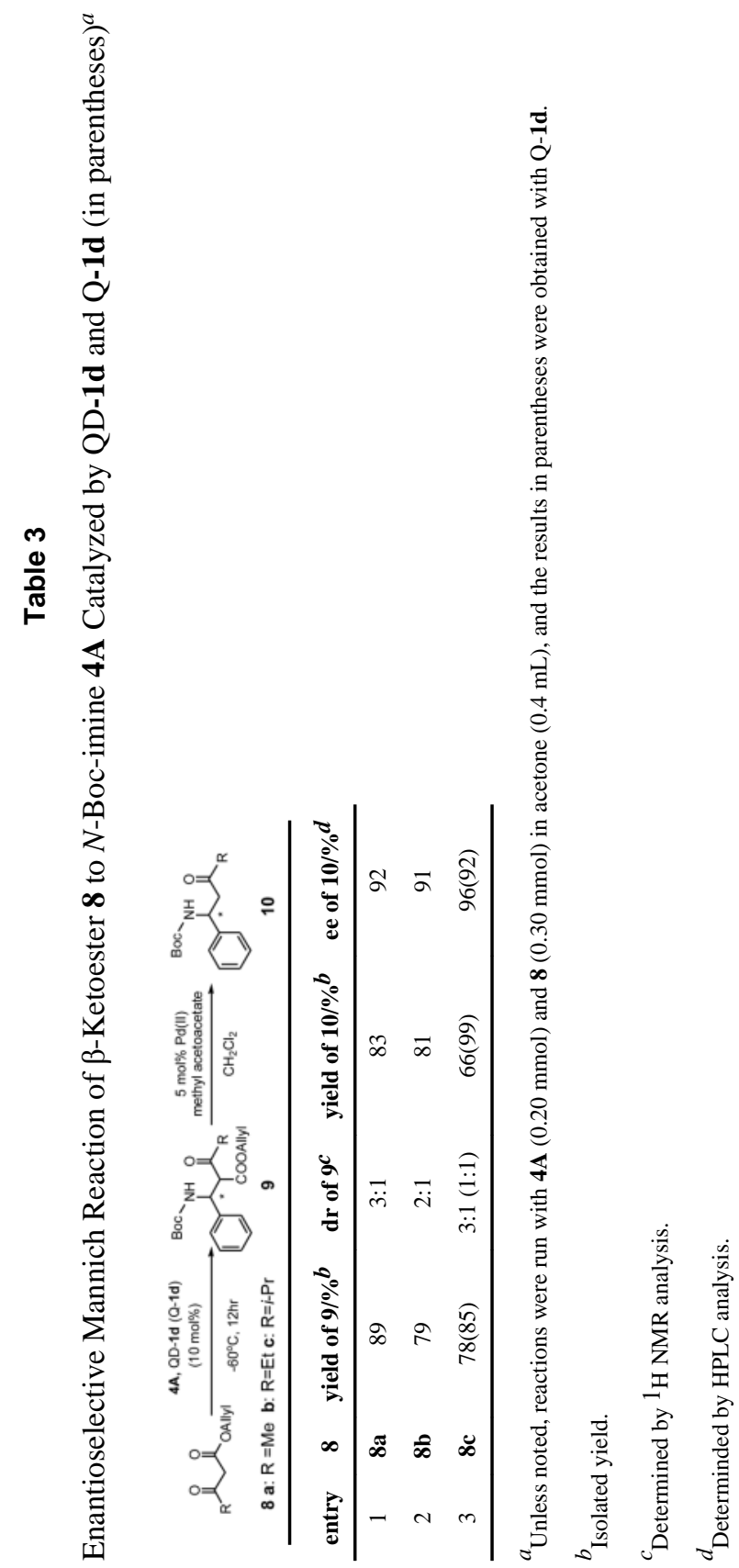

J Am Chem Soc. Author manuscript; available in PMC 2011 September 13. 